\title{
The Chinese Army
}

\section{Captain William Gill R.E.}

To cite this article: Captain William Gill R.E. (1880) The Chinese Army, Royal United Services Institution. Journal, 24:106, 358-377, DOI: 10.1080/03071848009418248

To link to this article: http://dx.doi.org/10.1080/03071848009418248

$$
\text { 曲 Published online: } 11 \text { Sep } 2009 .
$$

Submit your article to this journal

LII Article views: 8

Q View related articles $\longleftarrow$ 
Friday, April 30, 1880.

SiR RUTHERFORD ALCOCK, K.C.B., in the Chair.

\author{
THE CHINESE ARMY. \\ By Captain WiLLIAM GILL, R.E.
}

WuEs first asked to read a paper on the Chinese Army, I hesitated, for inasmuch as amongst the heterogeneous forces that compose it there is a complete want of what we understand by organization, the Chinese Army resolves itself into an unwieldy mass of men and matériel, which, even if complete information were to be obtained, would hardly furnish subject-matter for a critical audience. And eren now it can by no means be said that we hare at our disposal facts and figures sufficient to give us such a knowledge of the military strength of China as we have of European States, and I feared that I should fail to satisfy the just anticipation of those who might come here to-day with the hope of forming a fair idea of the Chinese Army.

Nor can I lay claim to the possession of much original knowledge, and the notes that I bring forward are little better than a compilation from other published works. Consideration has, howerer, led me to hope that, although the description of, and the informalon regarding, the Chinese Army that I can give, is meagre in the extreme, Jet that its anomalous condition in the present, aud the consideration of its possible future, will afford topies which are not only of the highest interest, but which most also present matter for deep thought as to the destiny in store for this most wonderful nation.

In order to understand aright the present state of military affairs in China-a condition of things that I have called anomalous-we must first glance at the later history of the Chinese Empire; and in order to form an opinion of the future, it is necessary to make an effort to comprehend the mental state of the Chinese nation.

I shall, therefore, commence by a brief account of the establishment of the present alien dynasty.

I propose, then, to give as good an account as I can of the present military forces of China, and to conclude by a consideration of future possibilities, based. on the idiosyncracies of the Chinese character and on the Chinese system of administration.

It was after many strange vicissitudes, after the rise and fall of many dynasties, after the appearance and extinction of Mongols, Kins, and Klitans, that the native Chinese dynasty of the Mings was established in 1368.

During the reign of the elerentlr monarch, the Eastern Tatars, or Manchus, first became numerous and troublesome. The first chieftain 
of these tribes who attained celebrity was Tien-Ming, who, in tle reign of the thirteenth Ming Emperor, published a manifesto in which he vowed vengeance against the Chinese for offences committed against him; and after his death his son continued the war he had commenced.

The misgovernment of the latter Mings had so alienated the affections of the Chinese people, that the country was orerrun with bands of insurgents, the leaders of each asserting a claim to the throne, and all of them rendering their country an easier prey to the warlike Manchns, who not only strove to subdue the Chinese, but endearoured also to bribe the troops from their allegiance.

At length a natire rebel, Le-Tze-Ching, who had, after eight jears' fighting, established his power over one-third of the country, entered Peking in 1614, when the Jast Mine Emperor, deserted and unsupported, first stabbed his daughter and then hung himself, thus ending the Ming dynasty, which lad lasted 276 years.

In spite of years of internal troubles, the supporters of the Ming dynasty had still on the borders a General, Wu-San-Kwei, at the head of an army efficient enough to keep off the Manchus.

And here it may be worth while to devote a few words to the consideration of the theory and practical working of the normal Chinese autocracy.

"The reigning Emperor of China is absolute because he is in the " eyes of his people the Son of Hearen, the chosen agent and repre" sentative on earth of the supreme ruling power or providence- of " which the Chinese have always had a lively conception under the " name of Teen or Heaven.

"The idea of divine right by birth has never" been known to the " national mind of the Chinese, and in modern times it is not posi"tively known during the reign of any one Sovereign who will be his "successor in the exercise of the divinely delegated power.

"Both in theory and in practice the primary claim to the snccessor" ship is giren by the death-bed or the testamentary nomination of " the reigning Sovereign; but it is by good government alone that the " nominee can fully establish his divine right.

"When by good gorernment, in accordance with the divine prin"ciples as laid down in the national sacred works, he has given or "preserved to the people peace and plenty, and as a consequence, " established himself in porrer by his hold on the national esteem and "affection, then only will they consider him, and then only will he " consider himself, the reritable Son of Heaven.

"Natural affection has almost always led to the nomination of a " relitive, mostly a son, but six of the Emperors of the present " dywasty have not been the eldest sons of their fathers, while the fact. " is ever present to the national mind that the revered ancient "monarchs Yaou and Shun each passed over his own son, because un. "worthy, and nominated a stranger."

Wn-San-Kwei, therefore, now found himself at a crisis at which he, like every other Chinaman, had to decide for himself whether the

"The Chinese and their Rebellions." By T. T. Meadorrs. 
"divine commission bad been withdrawn from the present loouse of

"Mings, and if so to whom it had been given.

" Had Wu-San-Krei and his army recognized Le-Tze-Ching as the

"new divinely appointed, it is possible that a new native dynasky

" rould have been established, and that, instead of the Manchus con-

"quering China, tle Chinese would hare annexed Manchuria."

IV u-San-Kwei, however, decided that the rebel Ise-Tze-Ching at all erents was not the new recipient of the divine commission, but, as he could not hope at once to fight him and also to keep out the Manchus, he decided to invite the co-operation of the latter, in the hopes that when he should have succeeded in crushing the native usurper he might find a means of expelling the foreign barbarians.

"It had always been an established principle that the true policy "towards all non-Chinese people or barbarians was to keep them off; "a temporary pressure of circumstances induced Wu-San-Kwei to "violate this rule, and the consequence was the subjection of his

" country to barbarians, and ultimately the extermination by them of " his own fnmily.

"Although looked on historically as a well-meaning. but unwise "statesman, he was undoubtedly an able General. He exercised a de"cisive influence on the fortunes of his country, and whenever he "fonght, either with or against his self-imposed auxiliaries, the " Manchus, he was always successful as a warrior."

It was in the year 1644 that at length the Manchus, with the aid of Wa-San-Kwei and many Chinese adherents, entered Peking and declared their young King Emperor.

"Wu-San-Kwei had bcen previously indaced to leave for the west " in pursuit of the usurper Le-Tze-Ching. At the death of the latter " rival the Manchus had recourse to the old system of feudal govern" ment, and by creating Wu-San-Kwef vassal prince of one or two " of the western provinces, obtained from him and the people nnder " him an acquiescence in the domination of a Manchu Sorereign at "Peling." 1

After a seven years' struggle, and by constitating three of the Chinese adberents above alluded to vassal princes of three southeastern provinces, that part of China was brought to a state of semisubjugation.

Later, abont 1673, when Kang-He, the second Emperor of the Manchu dynasty, attained his twentieth year, Wu-San-Kwei threw off his allegiance and marcbed an army northwards against the Emperor. The southern rassals joined him, but owing to disunion amongst the Chinese, Kang.He, who was a Sovereign of rare ability, and who, while retaining the hardy habits of his progenitors, had had the adrantages of a Chinese education, succeeded in the course of a ten years' war in completely conquering the south-eastern provinces and incorporating them into the centralized system.

Wu-San-Kwei died in 1678; in the following year the armies of Eang-He, the Manchu Emperor, marched westrards into his State, reduced it to subjection, and put every member of his family to death. 1 "The Chinese and their Rebellions." By T. T. Mreadows. 
His name, howerer, is not forgotten in those distant regions; and at the present time the river that winds at the base of the glorious mountain of Nen-Da is spanned by a bridgo said to hare been built by him, and across which he marched to clastise the barbarous mountain tribes.

Still the Manchus felt that their militars power was the original cause of their advent to dominion, and hence they naturally endearoured to retain it intact. Besides a very large Tatar garrison at Peking, they established smaller garrisons in many of the provincial capitals and in other important points in the provinces.

The forces of the alien Manchus are now known as the Banner Army, so called because the three nations that compose it are ranged under eight banners.

These three nations are-

1st. The Manchus.

2nd. The Mongol Tatars.

3rd. Chinese descended from those adherents of Wu-San-Kwei who entered Peking with the Manchus in 1644, and who afterwards furlished rassal princes for the south-eastern provinces.

They number ronghly some 230,000 non-commissioned officers and rivates, besides 40,000 élèves (paid expectants to the higher ranks), and 5,000 artificers and followers.

There are about 86,000 in Peking, another 50,000 are distribated bout the Province of Pe-Chih-Li. There are 40,000 in Manchuria, and the remainder furnish the Tatar garrisons of the chief cities hrouglout the Empire.

This force is in 41 grand dirisions, not all of the same strength, ach with its proper proportion of Officers of the nine grades.

The first is the Imperial Body Guard, 1,700 strong, for guarding the person and apartmentof the Sovereign. \&c.

Two others, 16,000 altogether, furnish guards for the palace gates,

The safety and order of the city of Peking are in charge of one of the grand divisions, called Pu-Kinn-Ying, numbering some 23,000 non-commissioned officers and men. 15,000 men are daily on duty, and are charged with the provention of robberies, murders, \&c.

There are small contingents for guarding the Imperial mausolea within and beyond the Great IVall.

Six grand divisions, numbering altogether some 40,000 , form the cordon of the 25 garrisons, and are stationed in the principal cities throughout a tract of country bounded on the north by the Great Wall from Kalgan to Shan-Hai-Kuan, and extending thence to the sea.

Four of these garrisons together forning the left wing cover Peking to the sonth-east, another five similarly form the right wing and cover the capital to the south-west.

Six garrisons, with their hend-quarters at Mih-Yun, are extended to the north-east and west.

The Shan-Hai-Kuan command of tive garrisons is spread from the sea along and within the wall as far as the Hsi-Feng-K'ou Pass.

Five garrisous form the Kalgan command, and there is besides a FOL. XXIT. 
strong garrison under a Tu-Tung (almost the highest military Officer), at Jehol, the summer palace of the Emperor.

But by far the most important of all the Banner Forces is that which is known as the Hiau-Ki.Ying, and which, according to Sir Thomas Wade, is the only corps which can have any claim to be con. sidered as an army. They number some 36,000 , besides 26,000 élèves.

But it is commonly believed that of the whole Banner Forces throughout the Empire, at the present time, no more than 30,000 of the Hiau.Ki-Ying in Peking, with perhaps another 18,000 of those that make up the 25 garrisons, can be said to be effective.

Even of these the whole do not, it is believed, drill in the European fashion; and if, at this date, they are all armed with modern weapons, it is as moch as can be said.

Information, however, is most difficult to obtain in Peking. Military exercises are almost universally carried on in the Inperial hunting park-an immense tract of country surrounded by a wall, the access to which is jealously forbidden to foreigners.

In, and perhaps also in the neighbourhood of, Peking, there is a force of field artillery with modern breech-loading gans, but of their numbers and effectiveness I can form no idea.

In the remote Western Provinces I can, from my own obserration, certify that what we should call soldiers have no existence; the men are there, doubtless, so are their wives and families, but bows and arrows, so far as I saw, were the weapons with which they were armed; and although it is by competitire examination that promotion is gained, when it is borne in mind that, for the most part, in those provinces remote from the capital, at all events, feats of physicul strength and proficiency with the bow are the subjects in which the aspirants io military honours are tested, it will be readily conceived that the vast number of men borne on the strength of the Tatar Bannermen are little better than a paper army.

Thus, like a mighty rock in the bed of a torrent, has China for centuries resisted the stream of civilization. Will it at length yield, and sweep onwards with resistless force? is a question that must engage the attention of all thoughtful minds.

This same army, however-contemptible thongh it may appear in its present condition-does, nerertheless, offer the basis on which may be raised the fabric of a complete and organized force. From the little that I have said, it will be-seen that the germs of an organization are even now not wanting. Life may some day be instilled, and a power of terrible might spring into existence.

The numbers that $I$ have giren are, as far as can be gathered, those mentioned in the Imperial books as receiving pay; but as the Manchu soldiers always have with them their wives and families, the-numbers in the Tatar cities are probably very much in excess of those reckoned. These Tatar cities, in fact, form with their inhabitants, species of military colonies.

Large cities in China are always surrounded by a strong wall, and many of the principal amongst them are divided into two parts b5 a wall as strong as that that surrounds the entire city. 
One of these parts forms the Tatar city, to which I lave just alluded, and which is entirely inhabited by these Bannermen and their families, and the other part is the regular Chinese city. There is not, so far as I am aware, any instance of a Tatar city entirely by itself.

The mere sight of the garrisons, Mrr. Meadows obserres, has been a continual reminder to the Chinese of their being under the dominion of an alien barbarous race; and as the latter have always borne them. selves with much of the insolence of conquerors, their acts hare been a constant excitement to disaffection. These garrisons form one deviation from the fundamental principles of Chinese government, as a partial attempt to substitute a physically supported despotism for a morally supported antocracy.

The next force that we have to consider is the Luh-Ying, or the troops of the Green Standard.

This force is composed entirely of Chinese, and is often by foreign writers inappropriately styled militia. It is, in fact, the Constitutional Army of China-the Banmermen being, as I have pointed out, the soldiers of an alien, though suzerain Power.

The duties of the Luh-Ying are, however, by no means confined to those of a European army; the responsibilities of a police force are imposed on them; by far the larger portion of the Luh-Ying land force seems to be devoted to the duty of preventing robbery, contrabandism, and other crimes. Thes escort stores-bullion to the Mint, or criminals from one jurisdiction to another; they assist at the collection of revenue; and the Officers charged with the supervision of river cmbankments, or the important duties of transmission of grain, have a certain force of Iuh-Ying at their disposal.

Besides the land force, the Luh-Ying mans the Nary of the seaboard provinces, and, as we have seen in the Banner Force, a distinct organization of divisions and garrisons, each under its General; so there is for each of the eighteen provinces a Chinese Army, complete in itself, and under the supreme control of the Governor-General of the Province; and also for the seaboard provinces a naval force.

So completely are these forces under the Governors-General of Prorinces, that even the Imperial Cabinet at Pehing finds it very difficult, and sometimes impossible, to induce these Officers to movo their army beyond the borders of their province.

The strength of these provincial armies varies with the size of the province, and with the duties they have to peiform.

Thus, in Kwan-Tung there are 43,000 of what are called mobile infantry, 22,000 garrison infantry, 2,000 cavalry, with nearly 800 Officers of various grades.

Of these 68,000 , about one-third are water soldiers, forming a naval force cantoned on shore; for this province has an extensive sea coast, and is liable to the depredations of pirates.

A large land army is necessary also, not only on account of its extensive area, but also because there are within its borders wild moun. taineers that hare to be kept in order.

In Ngan-Hui, again-an inland province inhabited exclusively by Chinese-there are no more than 8,000 of the Lah-Ying. 
Taking all the provinces, the average for cach is about $34,500 \mathrm{men}$, and 640 Officers-one Officer to 52 men.

Over each province in China there is generally a Governor-General, 1 or Tsung-Tn; bat, in some cases, there is but one Governor-General for two provinces. Under the Governor-General there is in every province an ofticial called a Fu-Tai, or Governor. This latter, though a civilian, is the Commauder-in-Chief of the Armies.

In this command he is assisted. by Generals and other military Offeers, but the chief command of an army, whether in peace or in war, is usually bestowed on civilians; for the Chinese hold military men of all grades more or less in contempt, inasmuch as the latter do not pass the literary examinations, and are without those literary qualifications and degrees which alone entitle Chinamen to the respect of their fellow.countryinen.

The Chinese think that a literary official whose talents have been severely tested, both by examination, and by the practice of often diffieult official duties, must be superior in every way to a military official, who is nnlearned, and whose talents hare not been proved. 'ihey argue also that talented literati, who, even though they may not have been occupied with military matters, yet must in the course of their studies have read much of them, will be better acquainted with strategy, and in every way better fitted for the command of an army than an ignorant military official.

Nor are they altogether withont reason. During the rebellion of the Tai-Pings, the Governor of Kuang-Si addressed a letter to the Governor of Hoo-Peh, urging the latter to send him troops as reinforcements. This letter dealt with many subjects, and in it the writer not only describes his own strategy with force and clearness, but he compares his own measures with those of the most celebrated Generals of history, such as Yang-Lao of the 10th century, and Sung-Pin, whose campaigns were fought 34 B.c., and with whose actions he was evidently well acquainted, he also shows a complete knowledge of the army organization of other ancient dynasties, and certainly in a large measure justifies the Chinese system of putting civilians in the chief command of the troops.

The Luh-Ying, or Forces of the Green Standard, are little more than a military constabulary. A small proportion are probably armed with modern weapons, some may be drilled in the European style, but though they must not be despised inasmuch as they, as well as the Bannermen, conld with energy and skilful Officers soon be organized into a great and powerfol army, yet as they are at present, they can be looked on as little better than a body of men, who would if called together be not very different from an armed mob. Indeed it is to be doubted if they are much, if at all, in a better state of organization, equipment, or discipline than they were some 30 years ago, when Sir Thomas, then M[r., Wade, wrote as follows:-

"But it is in the Luh-Ying Force that disorder runs riot, and the " bulk and distribution of this considered, the picture of its condition

I This Offeer is sometimes styled Vice-Roy by forcigners, but the title GoternorGeneral is much the better of the two. 
" drawn by members of the present Ministry best shows how defenceless "in the arm in which her chicf reliance should bo placed, is this great "Empire become."

Sir Thomas Wade then quotes amongst others the President of the Banqueting Court, who states that the troops of the Green Standard are unacquainted with the use of cannon, musket, sword, and spear.

Another laments that the Army is quite disorganized, the Officers falsify returns and make deductions from their soldiers' pay.

The ranks are half empty, half filled with ragabonds, of whom the weaker are incompetent, and the stronger in league with smugglers and robbers. Men whose names are on the roll send any fellow who has not the sense to earn his bread, as a substitute. Such desert before an cnemy, or never wait to come in front of onc.

In the letter to which I have already alladed, written by the Governor of the Province of Kuang-Si in 1851, that Officer speaks of "the cowardice of his troops." He says also " our troops have not a "tincture of discipline, retreating is easy to them, advancing difficult." The troops were all alike useless.

In July, 1851, the Peliing Gazette contained a memorial by the Lientenant-General of the Canton Bannermen (a Manchn): He states that the Army has never recovered from the disorganization caused by the want of success in the British War, so that the troops do not attend to orders, regard retreat on the eve of battle as old custom, and the abandonment of places they should hold as an ordinary affair.

But there is yet another force to be considered, and it is a strange illustration of the anomalons state of things that exists in the Chinese Empire, that we find the Governor-General of the province in which the Imperial capital is situated in possession of a large army, and that the only force worthy of the name in the Empire.

Li-Hung-Chang is the powerfal Governor-General of the Province of Pe-Chih-Li. It is beligred that he is much feared at Court, it has even been whispered that he has aspired to.be the founder of a new Chinese Imperial dynasty, and in any case it may be said that he is one of the most important men in China.

Li-Hung-Chang is a native of Seu-Chou in the Ho-Fei district of the Province of Ngan-Hui.

He was born somewhere abont 1830, and started in life as a sort of pleader in the yâmens of his native province. When the rebels inraded Ngan-Hui he was in command of a small irregalar force; he was invited to Nanking and became a secretary in the army of TsengKwo-Fan, then Governor-General of the two Kiang, and who was successful as a General against the Tai-Pings.

T'seng erentually nominated him in 1861 to be Governor (Fu-Tai) of Kiang-Su, which province was at this time overrun with rebels; and it will be recollected that he acted with Colonel Gordon at SuChou.

In. $1866 \mathrm{Li}$ succeeded his patron Tseng-Kwo-Fan as GorernorGeneral of the two provinces of Kiang: Si and Kiang-Su.

In the spring, of 1870 , he was ordered to march against the rebels in Shen-Si and Kan-Suh. At this time the Imperialist forces were 
under Tso-Tsung-Tang (familiarly known as Tso-Kung-Pao), and had been defeated by the rebels, who previously to the arrival of T'so had been forced back by the General To-Ta-Jen, who was killed in battle in 1866 ; and when Li marched from Wu-Chang-Fu up the Han river, the city of Si-Ngan-Fu was completely surrounded with rebels, and many people in it had died of starvation.

. Li-Hung-Chang was now in command of 40 battilions of the nominal strength of 500 men each; all these were armed with foreign arms of precision, and some of them had been drilled, more or less, by foreign Officers.

He had, however, scarcely arrived in Shen-Si, when the Tien-Tsin massacre took place, and he was called to $\mathrm{Pe}-\mathrm{Ch}$ ih-Li, of which Province he is now the Governor-General.

When Li-Hung-Chang returned to Tien-Tsin, he left his troops in Shen-Si, giving the command of them to General Liu, who, jealous of his military superior, Tso-Tsung-Tang, made little use of this force, the very name of which had been sufficient to drive the rebels out of the Province of Shen-Si.

In 1871 Liu was replaced by Tsao-Chu-1 [en, who with 22 battalions of Li's troops marched westwards, the other 18 battalions returning with Lia to Pe-Chih-Li.

Of the present numbers and constitution of this army of Li-HungChang, very little is known, and I regret that I am unable to do more than indicate its existence. Whether any of the 22 battalions left by Lin in Shen-Si have since returned to Pe-Chil-Li, I cannot say; but it is certain that Li-Hung-Chang has now a verg large number of wellarmed troops.

They are chiefly cantoned in the neighbourhood of Tien-Tsin, and they garrison the forts at Ta-Ka and Peh-Tang, which are hearily armed with Krupp guns.

In the army of Li-Hung-Chang, there is also a fair proportion of field artillers armea with Krupp gans.

The soldiers are mostly natives of Ho:Nan and Ngan-Hai (Li's native province). It is said that some are drawn from the Luh.Ying or forces of the Green Standard, many serred under Li-Hung.Chang during the rebellion of the Tai-Pings, and some come from the ranks of the Tai-Ping rebels themselves.

In East and West Kan-Suh, the regular army as enumerated in the Imperial books should be some 10,000 Bannermen, and about 50,000 of the troops of the Green Standard.

But during the last ten years, armies have been despatched thither and beyond to Ili and Kulja, both from Yun-Nan, and as I have before stated from Shen-Si, and I am not aware that the materials exist for an accurate estimate of the total strength of the force that is now free to face the Russians.

The Yun-Nan army was that set free after the capture of Ta-Li-Fu and the final overthrow of the so-called Panthays, and which marched to Kan-Sub to assist in the war in the far west.

Very little is known of the composition of this Kan-Suh army, but as far as can be gathered, the total force employed by the victorious 
General-in-Chief, Tso-Tsung-Tang, seems to have been some 60,000 to 100,000 men. Richthofen says, that in 1872 the Governor-General of Kan-Suh had the immediate command of 200 battalions, not connting the troops of Li-Hung-Chang, then under General Liu.

These were mostly, if not entirely, armed with breech-loading rifles, and there was also a fair proportion of field artillery with them.

That the performances of this army are highly creditable mast be at once admitted. The march itself from Ta-Li- $F_{n}$ of any considerable body of men would be sufficient to take a place in the annals of military achievements. No one who has not travelled in the East can form a conception of the badness of the mountain tracks, and tho difficulties to be orercome; and at that time immediately after the terrible rebellion in Yun-Nan it can have been no easy matter to hare fod the army in a country laid desolate and devastated. by both sides in what was almost a war of extermination.

The march of these men and the other Chinese armies from Lan-Chou-Fu to the oasis of Hami, a distance of about 1;000 miles, a portion across a completely arid and waterless region in the fearfal Desert of Gobi, must fill us Englishmen with enrf, whose miniature armies are always accompanied by huge and cumbersome baggagetrains that would render feats such as these of the Chinese, utterly beyond our powers.

But at the same time it must ever be borne in mind that there is in no part of China at the present moment any force that in a European sense can be called a disciplined army.

I have quoted official reports: written about $1850 \%$ on the state of the Luh-Ying, and I will now give the remarks. of Baron ron Richthofen, written in January, 1872, at Si-Ngan-Fu, where at that date a large number of the arny that afterwards marched westwards were gathered together.

"Since - my entry into Shen-Si, I have been constantly amongst " soldiers and Officers. . Lmong the latter there are men of a military " turn of mind, who in time of war will do honour to their position. "Nor are the soldiers, who are mostly from. Ho-Nan and Hu-Nan, " made of bad stuff. They have mostly a stout frame, and can stand "fatigues remarkably well. But they are not animated by either a " military or a patriotic spirit, and the only means to kcepas slight "discipline among them is the fearful power of capital punishment, " which every Commander of at least one battalion wields over his " own men. It is made use of liberally, and many are the soldiers' " heads that are cut off by the executioner.

"Can there be any more forcible illustration of: the complete lack " of military spirit than this, that the executioner is one of the com" rades of" the criminal, and receives 500 - cash (about $2 s$.) for cutting "off his head?"

The victories of this Chinese Army are not difficalt to account for; they are due not to the superior discipline or valour of the troops; it is. probable that so far as valour is concerned, the Mahomedan rebels and; the forces of Yakub Beg were at least their equals, if not their. superiors. But their superiority lay in their arms. 
I have already referred to the fact that the very name of Li-Hung. Chang's troops had been sufficient to drive the Hwei-Hwei rebels out of Shen-Si.

Of this event, Baron Richthofen remarks, "The fame of Li.Hung"Chang (or perhaps of his foreign arms) is so great that the rebels " withdrew imnediately on the approach of his troops, never engaging " in a fight with them. No one of the soldiers of that army whom "I met has ever seen a rebel. The whole province of Shen.Si was at " once cleared of organized rebels, witlout bloodshed, none but "stragglers remaining. The main body retired into Kan-Suh. ". . . . . . The province will remain in a peaceful condition " as long as it is occupied by foreign armed troops."

The best armed and organized troops with which the Chinese Army with their Berdan rifles and Krupp guns had to contend, were those of Yakub Beg. The army of that potentate is thus described by Mr. Boulger: "The army of the Amir was divided into two bodies, " the jigit or horse soldier, and the sarbaz, or foot soldier. The jigits "were armed with a long single-barrelled gun and a sabre. The " sarbaz, among whom are included the artillery, had gone through "some regular drill and training. He was a regular soldier, and " might be trusted in defence of his country up to a certain point. "It is probable that Yakub Beg never had 20,000 trustworthy soldiers " in his army."

When we consider the moral effect alone that mast be produced on the mind of ignorant and superstitious people by the rague knowledge that their foes are armed with foreign weapons, of which they have the most exaggerated ideas, it will readily be beliered that it was neither superior courage, discipline, nor generalship that gave such complete victory to the Chinese, but that these were due to superior arms and superior numbers directed by an all-powerful will at the capital; a will which, though it may be slow in making itself felt, is nevertheless felt and obeyed throughout the length and breadth of the Clinese Empire.

But this paper will hardly be complete without some consideration of the future; I have no intention, however, of clothing myself in the mantle of a prophet, but by some examination of the past, I hope that it may be possible to laj some slight basis for speculation.

And at the outset we cannot but be appalled by the magnitude of the task. We have here a nation that is spread over an area, the very rastness of which is itself difficult to appreciate; and its numbers eren in preportion to the territory are still immense. This nation possesses an rathentic political history for 4,200 jears, and even at the time when our forefathers knew no other clothing than blue paint, it was almost the nation of the day.

This nation possesses no landed aristocracy, but you may find men in it who can trace an anthentic pedigree for 2,000 years; and it boasts what no Western nation can claim in so high a degree-an aristocracy of intellect.

This great Empire has now lived throngh long ages of raried for- 
tune, and it would be surprising indeed if a people that had survived so many and such great vicissitudes, had been conquered many times, and had cach time risen superior to defeat, had absorbed one race of conquerors and had driven out another, did not possess some characteristic that would mark it as a peculiar people, and this characteristic is the individuality of the race. And it seems to me that it is only by an inquirs into the causes of this individaality, and of the long duration and stability of the Chinese Empire, that re can hope to speculate on its future as a military Power.

When first the Chinese nation became known to the West its stability was attributed to the doctrine of filial piety, which was and is universally accepted by the people.

It has also been ascribed to the geographical isolntion of the Empire, and to the peculiar pature of the Chinese written language.

Another theory is, that it is due to the assertion of a Divine Harmony in the Universe, which has been throughout all ages the fundamental and ruling ides in every Chinaman's principles of action.

Mr. Meadows considers that the real causes of the nnequalled duration and constant increase of the Chinese people, as one and the same nation, consist of three doctrines, together with an institution, by means of which the efficient performance of the work prescribed by two of these doctrines is attained, and by which a living practical belief in all three is maintained in the mind of the nation.

The doctrines are-

I. That the nation must be gorerned by moral agency in preference to physical force.

II. That the services of the wisest and ablest men in the nation are indispensable to good government.

III. That the people have the right to depose a Sovereign who either from active wickedness or vicious indolence gives cause to oppressive and tyrannical rale.

The institution is -

The system of public service competitive examinations.

MIr. Neadows observes:-

"In every case the institution of public service examinations (which " have long been strictly competirive) is the cause of the continued "duration of the Chinese nation: it is that which preserves the other " causes and gives efficacy to their operation.".

It appears to me that the first doctrine enumerated by Mr. Meadows embodies the theory of the Divine Harmony-a theory that may perhaps bring a smile to the unthinking.

But thos: who have scen and felt that the Chinese character and ways of taought are not as ours are, will pause before condemning any theory, however insufficient it may scem, to account for the marrellous history we are now contemplating.

With regard to competitive examination, however, it must not be forgotten that the system was only introduced in the comparatively modern period of the Tang dynasty (circ. 700 A.D.).

The nation had then already existed 3,000 jears, it was eren then practically the nation of to-day; and surely, therefore, there must be 
something deeper than the examination system to account for this marvellous individuality.

The formation of the character of individuals is a subject that has scarcely, if at all, been stadied; the formation of the character of a nation must therefore be a gigantic task. Deeply interesting though it would be, the inquiry into the formation of the Chinese character is one that no one wonld lightly undertake, and I shall certainly not venture to discuss it here. I shall content myself with believing that the individaality of the Chineso race has developed itself with the nation, and that the roots of it lie buried among tho crumbling ruins of dynasties, which may even zet, like the mounds of Nineveh, some day afford startling revelations for the diligent searcher into the records of the past.

But eren though. we may doubt that competitive examination is the cause of the continued duration of the nation, there can be but little question that the three doctrines already enunciated must have contributed to it in a large degree, eren if they are not, as I am inclined to thinl: they are, the sole canse of it. Nor cau it be questioned that the system of competitive examination assists materially to maintain the work prescribed by these doctrines.

Mr. Meadows observes:-

"The desire of raiging himself above his fellow-creatures is one of " the strongest passions of man's nature: hence if even a probability " of advancement is held out to him as soon as he shall be worthy of " it, his exertions are immediately increased; while if the certainty be " there, it is no exaggeration to say that they are doubled and trebled."

It is this desire of distinguishing himself that is the passion acted. on systematically by the Chinese polity.

In China the only posts of distinction are those of Government. serrants. The only road to them is by competitive examination, and the literary graduate, even though he only be an expectant for official service, and however poor he may be, is much more respected, and really possesses a greater practical iufluence, than the rich but unlearned merchant or landed proprietor; and thas does the State secare the servies of the wisest and ablest men, and hence the only class that has to be repressed by the Gorernment officials is nearly entirely composed of men of mean ability.

Having thus, in as few words as possible, stated what may be the cause of the long stability of the Chinese nation, a question at once presents itself to us, and one by no means easy of solution.

For those who have studied Chinese history, and have traced backwards the line of dynasties through the din twilight of the earliest records till they have at length lost them in the darkness of fabled antiquity; those who have marrelled at the gigantic works and the arvanced knowledge of the Chinese of long ago, who hare been startled by the fact that a reference to the culmination of stars shows that the Chinese historical classic must have been written at least 4,000 years since, and who have been dazzled with the splendour of some epochs in Chinese history, cannot fail to be lost in sorrowful amazement at the stagnation of the last few centuries, and to ask 
themselres what it is that has arrester in its growth the civilization of this wondrous people.

It may seem rash to attempt a reply to such a question, but as the prospects of the future depend upon it, and as each new theory may contain some grain of truth, I venture to give my opinion. And I think that this very system of competitive examination, although it has tended to perpetuate the nation, has nevertheless tended to perpetuate it in an unchanging condition, and has materially contributed to the stagnation which forces itself upon our attention as one of the most marrellous facts of history.

There is now no time to discass this matter, but I would briefly point out, in the first place, that the subjects of these examinations are not such as to prodnce originality of ideas, but that they rather tend to force the whole national mind into one groove of thought, and that a very narrow one.

Thus, without originality and devoid as the Chinese are of imagination, it is not difficult to understand why they should have ceased to advance.

Further, the very fact that all the talent of the country is absorber in the service of the State must tend to hinder the advancement of the nation. For even in progressive countries a system which would divert from private enterprise all those who help to make the conntry great would have lamentable results. How much more must this be the case in one where enterprise of any kind is almost unknown, and which has, as it were, been asleep for centuries? In Western States, honour, fame, and dignities attend those who succed, no matter in what walk of life; but in China none but the officials can hope for any of these. If wo look back at the history of our civilization, we find that all the great strides in science, and nearly all the greatest works of literature and art have been due to private individuals. The discovery of America, the establishment of the overland route to India by Waghorn, the Suez Canal, and nerspaper correspondence are but a fow instances; and in this country does not the Government always look with suspicion on any measure that would appear likely to interfere with or reted individual effort?

It may seem that I have been somewhat deviating from my subject; but $I$ think it will be admitted that the considerations into which $I$ hare entered were necessary for the due prosecution of the great inquiry, How far is China likely to take her place in the future in the rank of great military nations?

This inquiry naturally divides itself into the questions:--

1. What material is there in China for making soldiers?

2. What for the production of Officers? And

3. Witlout altering the fundamental principles of Chinese polity, what changes in the details of the system are necessary to raise from the Chinese people the Generals and subordinate Officers necessary?

The answer to the question, What material is there in China for making good private soldiers? is easy. .

The Chinese, especially those of the north, are a fine people physically : they are hardy and enduring, frugal and temperate; they can 
undergo great fatigues nn a small amount of food, and will support great privations without complaint. They are law-abiding, docile and obedient to authority; and if the discipline in their armies is at present lax, the history of Gordon's force shows us what it might bo if the soldiers were properly paid, properly officered, and properly looked after.

In his listory of the "Erer Victorious Army," the author writes :"Sometimes a regiment would be a whole month without anyone " in it deserring punishment, and the relationship between the men and "the Officers was on the whole affectionate. The Chinese were, as a " rule, very orderly; and as drunkenness was unknown amongst them, " the serrices of the Provost-Marshal rarely came into use, except " after a capture, when the desire to loot was a temptation to absence "from the ranks."

The other qualification requisite for a soldier is courage; and although I would at the outset state that, owing to his edueation and surroundings, I do not believe that the Chinese possess any. leroic feeling of derotion, yet I think there can be no reason for the assumption that has been made that they are a cowardly race.

I think, on the contrary, with Mr. Meadows, that:-

"The Chinese possess as much of constitutional or animal courage "as any other specimens of the human race, but of that courage " which is based on a determination of the mind to display intrepidity, " they are nationally wanting, simply because their own opinions and "institutions offer little inducement to their minds to come to any "such determination."

In England we aire taught to regard bravery and warlike talents as among the highest of human qualities. In China, on the contrary, the national education tends rather to reduce the military virtues to a low place.

There was, no doubt, at one time, a prevalent belief in the West that the Chinese were a cowardly people, and the case with which English troops beat Chinese after a mere show of resistance has been adduced as a proof of it. tion.

A little consideration, however, will show the error of the assump-

The English were armed with weapons that they knew were infinitely superior to those of the Chinese-they had been brought up to look upon military valour as a very high virtue-they knew that disgrace followed cowardice, and that, at least, honour was the reward of valour. They knew that there were pensions for themselves if disabled, and for their widows in case of death; above all, they had confidence in the skill of their leaders and the courage of their Officers.

To the Chinese, on the other hand, all these incentives were wanting. They not only knew that the foreign arms were deadly, but they had the most exaggerated ideas of their power and effects. They had passed their lives in a society were military virtues were regarded as of little moment, and where military Officers were looked upon with little better than contempt. With them a panic, and even a headlong flight, 1 "Desultory Notes." By T. T. Meadows. 
by no means brought disgrace, and they were well aware that the highest courage would meet with little, if ans, reward. They were miserably paid, often not paid at all, and pensions are quite unknown. Finally, they had every reason to know that their Generals were in. competent, and no reason to suppose their Officers were animated by any higher spirit than themselves.

Under these circnmstances, is it reasonable to accuse the Chinese of want of courage, becausc they did not offer more scrious resistance to our troops?

There are, morcover, instances on record that fully corroborate what I have stated.

Wilson, in his " Ever Victorious Army," states that-

"As sappers, the Chinese are equal to any Earopeans. They work "well, are quite cool, from their apathetic nature; and however great "their losses, do not become restless ander fire, liko Earopenus."

It is universally acknowledged that, even with the best disciplined soldiers, it is a mark of the highest training when troops ean be brought to assault a second time immediately after a repulse; but at the siege of Tai-Tsan, after the storming party had already once been driven from the breach, it was assaulted a second time within half an hour, and carried; and at Kin-Tang, three successive assaults were made which were desperately resisted by the rebels.

Another instance is quoted by the same author, who writes:-

" Four rebel horsemen rode past the steamer in a shower of ballets, " and when one of them was strack off his steed, the others waited for" " him and carried him off--a fine instance of Chinese courage and "fidelity."

Instances could be multiplied to an almost nnlimited extent, and the opinion of many other thinking men might be brought forward. But I believe that I have said enough to show that the Chinese, if properly trained, properly armed, and properly led, by Officers in whom they placed confidence, would certainly furnish material for admirable soldiers.

But, on the other hand, it is my opinion that, for two very sufficieut reasons, the Chinese will not make good Officers.

The first is, that the Chinese are, as a nation, entirely without observation and altogether devoid of originality. A Chiraman can learn anything, but he can conceive nothing; he may readily be taught any number of the most complicated military manonvres; but place him in a position slightly different from that in which he has learnt, and $l_{1} \theta$ will be found incapable of conceiring any modification to suit the altered circumstances.

Prompt action, readiness of resource, ability to seize on the smallest advantage, or to neutralize a misfortune; these are the qualities that make a soldier, and these are the qualities that cannot coexist with the Chinese want of originality.

The other reason is that to which I have already alluded, the national want of that courage which is based on a determination of the mind to display intrepidity-the national want of anf feeling akin to self-sacritice in the cause of duty. 
If we look at the history of the world, we shall find that two mighty influences have been at work to induce such a feeling as that of self-sacrifice-the first has been religion, and the second the desire so strongly implanted in the human breast of gaining the esteem of fellow-man. Indeed, I doubt if I shall be guilty of exaggeration, if I assert that all great, virtuous, and noble actions hare been prompted by one or the other.

When, therefore, we bear in mind that at all events, so far as military virtues are concerned, both of these influeuces are completely wanting to a Chinaman, we must be driven to the conclusion that we shall not find these military virtues in China. This leads us to the con. clusion of the paper, the considerations of the future possibilities; and as $I$ hare already pointed out, what are in my humble estimation the wants in the Chinese system, I have to a certain extent indicated the remedies; and these would be-

First, the admission of military men to positions of honour and esteem at present only open to civilian literati. tions.

Secondly, an alteration in the subjects of the competitire examina.

With regard to the first, I will quote the words of Manderille, who, in writing of the Romans, said :-

"But if we would know what made them excel in fortitude, courage, " and magnanimity, we must cast our eses on the pomp of their "triumphs, the magnificence of their monuments and arches; their "trophies, statues, and inscriptions, the rariety of their military "crowns, their honors decreed to the dead, public encomiums on the "living, and other imaginary rewards they bestowed on men of merit; " and we shall find that what carried so many of them to the utmost "pitch of self-denial, was nothing but their policy of making use of " the most effectual means that human pride could be flattered with."

With regard to the second, however, it is held by some whose opinions are entitled to the highest respect, that from the very fact that the subjects of the examinations have beeu for centuries the revered ancient books, and these alone, so the national mind has been moulded in uniformity; that it is owing to this and this alone that the same ideas have pervaded the whole Chinese nation; that it is this that has produced the marked individuality of the race, and has allowed it to remain homogeneous and united amid the rise and fall of so many Empires.

I have little doubt that if the exact sciences were introduced into the Chinese curricnlum, in course of time originality would be developed, and China might produce a Tyndall or a Newton. It is to be believed that if the military examinations were something better than the childish exercises now in vogue, a race of Officers might appear worthy of a great nation; but then the momentous question arises-a question that must ore now hare presented itself with terrible force to some minds in China-That would be the effect of scientific education and its necessary concomitant free thought; would it be possible any longer to keep 300,000,000 of people united; would not the spirit of change or revolntion be let loose, and, bursting 
the floodgates that so long had held it back, sweep a way the landmarks of centuries, tear up the roots of existing institutions, and leave China even as Assyria, Egypt, and Babylon, a mystery to future generatious?

The Clnarmar: We hare had a rery interesting paper on the subject that Captain Gill has brought before us. We ought to have had Colonel Gordon, the Commander of the "ever rictorious army," here, who certainly knows more on this subject thau anyone else can possibly do, who has seen the Chinese first in their ragged state, and afterwards succecded in welding them into a force rery nuch like the Duke of Wellington's Peninsular Army, who could "go anywhere and do "anything." I hope that there are some gentlemen here who can gire us some information on this subject. The main question raised by Captain Gill is now far it is possible, giren an unlimited number of men, with many of the best qualities of endurance, hardihood, and temperance, and giren arms of precision, can you make nn army out of them, bacause if rou can, Jou hare got all those first elements in the Chinese Erapire, and they hase now got arms of the best quality? The question is whether, by a better system of education for the native Olficers, and by employing foreign Officers to drill and instruct them, they could not be welded into a great army. That is a question upon which I should hope some soldiers here, who hare been in contact with $\Delta$ siatic races, may gire us some information.

Mr. DeMetrics BodLGER: There are two points mentioned by the lecturer upon which.I should like to say a few words. The first is this:-Captain Gill seems to me to sketch the future of the Chincse Army only if the Chinese are willing to accept foreign Officcrs, in order to raise their natire army to a high state of perfection. I venture to think that there is rery little evidenee in farour of the view that the Chinese are willing to make more than a temporary use of foreign Officers. The great point in the Chinese policy is to depend upon themselves, and I think it would be nursing a fallacy to suppose that the Chinese will at any time accept foreign Offeers as a permanent etaff. They may, forced by some necessity that mar arise in consequence of foreign war, make a temporary use of foreign Officers or foreign superintendents, as they are at the present moment at their great arsenal at Kiang-nan, but, as soon as they lare served their purpose for the moment, they will try and get rid of them. The secret of the Chinese policy is dependence upon themselves, and, 23 soon as they have raised their army to a certain, though a rery imperfect, state of efficiency, they will be content rather than striro to attain a higher state by the aid of foreign Officers. Anotber point I would wish to touch upon is this. Captain Gill seems to think it is hopeless to expect from the Chinese any originality. Now, I think the past history of China shows they hare rery often, before even they had any assistance at all from foreigners, produced great Generals. Anyone who has read the campaigns of one huodred and fifty years ago will admit that Fejanku, who xas Kang Hi's General; that Chowmodo, who appeared like a Ilearen-sent champion when the Chinese were at the list stage of distress in Central Asia, and defeated Amursana, and also General Foutè, who marched not only across the Desert of Gobi, but across the Pamir and defeated, in two battles, the Kashgar Prince on the crest of the Pamir, on the borders of Badakshan, were all great Generals. These cases show that the Chinese hare produced Generals in the past, who showed originality and power of conception; and, therefore, the Chinese are, to some extent, justified in beliering that, as they possessed thise natire Oficers and Generals in the past, they may in the future have the same. It is very important to call attention to the manufacture of reapons at the Kiang-nan Arsenal. It is not generally known that, at tinat arsenal last year, they produced twenty 40-pouncier Armstrong guns, which were tested by European engineers, who said they werc as good as if they had been turned out at Elswick or Woolwich. They have also turned out 7-inch 150-pounders, which hare stood the same test, and my information states that those guns, made on the pattern of Armstrong's, have been sent on active service.

The Cirsiryas: I would reature to offer a few remarks on the subject generally, baring spent a great many ycars in China, and had some opportunity of secing the Chinese soldiers both in war and in peace. For more than twelro months there was 
an Imperial Arms surrounding Shanghai, while the insurgents held possession of the city, and there was a great deal of fighting going on. Indeed, once or twice I had to take an actire part, with some of our blue.jackets and marines, in at tacking one of their fortified camps. I hare always been struck by the pluck they showed in fighting at all, under the conditions in which thes were placed. At that time they were badly armed, they were clothed in a sort of Falstaff uniform, and they were often deficient in rations. They were always in arrear of pay, and, if wounded, they had no hope of surgical aid to sare their limbs, no hospitals for treatment, nor of any pension afterwards. Nor, a man must hare the combatire instinct in him to fight at all under such conditions, especially as they are deficient, to a great estent, in what we know us patriotism. The Empire is so rast, with an arca of some 4,000,000 square miles, and a coast line of orer 3,000 miles, while its cightecn provinces really represent almost so many different countries, with diversity of languages and interests, so that, as wo contimually experienced in our own wars with the Empire, it was nothing uncommon for war to be going on in one prorince while in another they were dealing with us in the most peaceful way in the world, both authorities and people, eren when our armies were marching on Peking! So that, taking away those conditions which generally lead men to fight--lore of distinction and lore of country, with the certainty that they will be duly cared for, if wounded, and rewarded, if successful-abstracting, I say, those conditions, it is a marrel to me that they fight at all. But, as they do fight, it is quite certain that they hare the great qualities of animal courage and contempt of danger, and it is unfair, therefore, to speak or think of them as being cowardly. They only require to be well led, but shen you hare a body of not very well disciplined men, and their officers get behind some ruins, as I hare secn, and tell the men to "go on," instead of following their lead, you cannot expect much from them. We all know, in our own Army the Officers $8 a y$ "Come on!" which mikes all the difference. I beliere, as Colonel Gordon proved, that well and courageously led, licked into some sort of shape under discipline, and with good arms, it would be easy enough, in the course of a singlo year, to make them into a rery formiduble army, even to Europeans. They hare taken two necessary steps at present. Ther hare acquired a certain amount of drill and instruction, and they hare arms. I beliere the greater part of the real fighting army is in possession of the best arms of precision that are made, and if they had only Officers capable and were well disciplined, they would beconio formidablo against any enemy. But what Mr. Boulger said is exceelingly true, that the jealousy of the foreign element is so great, and their desire to be independent and to derelop for themselres whaterer is likely to be beneficial is so strong, that they are continually changing their Offecrs, and they nerer will keep them long enough or gire them sufficient authority and influence orer their men, to make them into regiments. It is not enough merely to drill men, but their Officers must hare a certain continuous influence orer them; it is that which makes them into soldiers and an army fit for serrice. So long, howerer, as they go on in their present halfhearted fashion, they may spend enormous sums of mones, as they hase done already, and to very little result. I hare seen the gromth, in ten years, of dockyards and arsenals, at Tientsin and elsewhere, founded on the plan of our own, and when I was there last, I found some of the best Woolwich workmen had been induced to come orer to them. They, with such lielp, can turn out arms and ships, but if they go no further than that, their money is almost thrown away, and if they are to come into contact with Russia, notwithstanding all their pluck, they can hare ro fair chance. To make a soldier you must hare something more than arms and uniform; you must make him a soldier, and that can only be done by good Ollicers and constant discipline and drill. As to the Central dsian question, the Chinese are coufronting Russia, and are rery much bent on defending what is the great gateway into their western prorinces. The Kiagu Pass, which is at the extremity of the Great Wall, leaus by the shortest route across the Desert of Gobi, to Kuldja and to Yarkand, and it has been, from time immemorial, the traditional lime of communication and traflic betreen China and Central and Western dsia. All the commerce and traffic which has ever taken place between them, has gone in that direction. It is also their re:lhest point, becauso it opens through all the wealthy prorinces on the west, and they have al mays watched the frontiers and pass with considerable 
rigilance under the present Manchu dynasty. There is no doubt, I think, that they regard the approach of Russia in that dircetion, and the desire which the latter bare shown to hold a part of the prorince of Ili, that once belonged to China, and more especially the tomn and district of Kuldja, as a danger, if not a standing menace, to occupy in strength this road, whish leads into their western proviuces. But $I$ think it probable that, with their usual tenacity of purpose and a General like Tso-Tsung-Tang, who has certainly prored that he has considerablo militury ability and power of leading his troops, ther will prore unpleasant neighbours to the Russians in Turkestan, unless the latter can come to some diplomatic compromise. Feeling thus, I have no doubt there will be some collision between the Russians and Chinese; but there is this to be considered, that the defeat of a Chinese Army is no great matter to the Gorernment at Peking; men are abundant, and they will get more armies; and distance is no impediment, because they march enormous distanees. In all their history they hare nlwajs shown that thousands of miles do not stop them. But with Rusia, a defeat is a loss of prestige, a luss of power, that would be attended with serions consequences. This therefore a little re-dresses the balanco and tends to lessen the disparity between the forces at the disposal of each. Cuina can afiord to loso army after army, or to incur defeats one after the other, without its shaking the Chinese throne, and such rererses would not in the least modify their determination to hold their own. But if Russia engages in a war at that distant point from her centres and her base of operations on the Caspian, of course a single defeat might have very serious consequences. I am sure you will allow me to thank Captain Gill, in your narae, for the very raluable information he has giren us on the Army of China, which, in the present aspect of affairs, has indeed a specinl inlerest.

Captain GiLL: I should like to say a word or two with regard to what MIr. Boulger has said: I quite agree with him in thinking that the Chinese will nerer accept foreign Officers in their army as a fermanent arrangement. I think it is a rery grcat question whether any nation could hope to raise itself amongst military Potrers which is dependent upon forcign resources for its Olitcers. I did not mean in the least to insinuate that the Chinese would ever take forcign Oficers ns a permanent part of their body politic. As to originality, I nust sar, from my own experience of the Chinese, that $I$ consider that originality is a thing that is almost non-existent in the Chinese nature. I do not beliere that, under the present system of examination, which so narrows their minds, any really original genius rrould erer arise, or that with that system they would erer be able to proride efficient and good Officers and make an army, as we understand it. Of couree it is possible that there are instances on record of considerable military skill haring been shown by their Generals on nany ocensions. At the same time I must say that I a there to my orn opinion that there is a great want of originality in the Clainese, which will prerent them from being a great military nation.

POL. XXIY. 